\title{
富山県一農家 (佐伯家)の明和年間の家作とその文書
}

\author{
正会員宮 沢 智 士*
}

\section{1. 概 要}

佐伯家は富山県西砥波郡福岡町㝨島にある。研波平野 の西北部にあたる。この平野の村落は散村として知られ ており，佐伯家もそのひとつの典型をしめしている（図 一1)。屋敷地は $3000 \mathrm{~m}^{2}$ ほどあり，主屋はそのほぼ中 央にたち，他の多くの例と同様に東面する。主屋のほ か，門・離れ座敷・倉・作業場などの建物がある。敷地 の南西北酒に素敷林が繁り，用水がまわる。用水を利用 した池もつくられている。㡷敷や家の規模から外て，位 们家は上層に禹する農家であると掞もわれる。

この家の主屋は明和 4 年：「家作諸人用一专」と題する 袋と衣一1・図一2にあげる5冊の所蔵の家作文書によ ，て，明和 5 年：(1768) に移築したものであることが知 られる。家作文書の内容にはのちに詳しくふれるが，そ の記載に一部重複があって，すべてを独立した内㝘をも つ史料とすることはできない。また記載には断片的な部 分もある。このため本稿では, 最初に重複する部分や断 片的な部分を整理し，史料の全体をつかみ，估伯家明和 年間の家作の状況, 特に家作における村人の協同の様子 を明らかにしよらとするものである。

家作における村人の協同の状況は，民家の建築それ自 身と同様に，地域的な特徵をもち，時代とともに変化し ているとみられ，その地域の社会・経済の状況を反映し ている。またその家が属している階層によってもたいい ん様相を異にしている。そしてこれらの違いが民家に豊

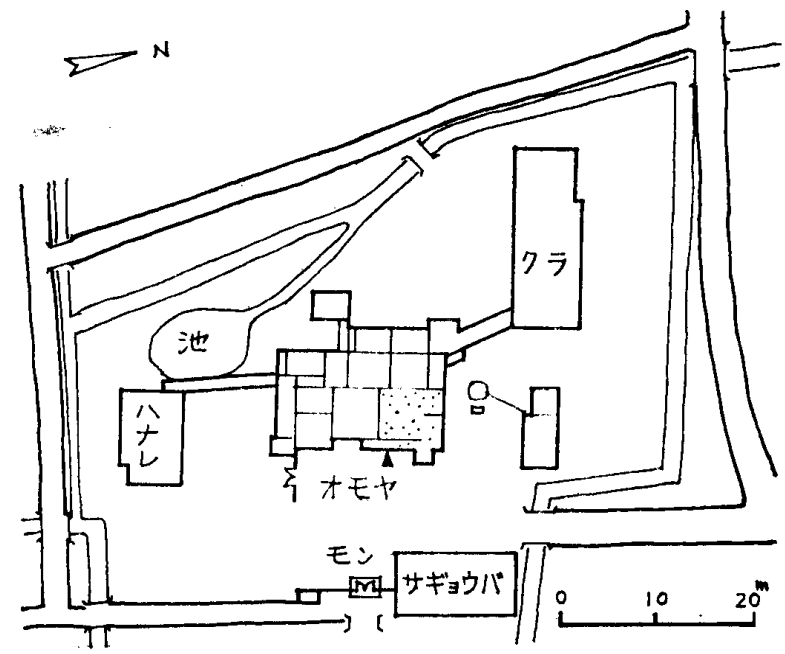

図-1 佉伯家住宅配置図

* 奈良国立文化財研究所 (昭和 46 年 9 月 11 日本稿受理・唁論期限昭和 47 年 6 月末日)
富な地域性をむたらしているものと考えられる。

民家の家作の方法は，村人の協同のあり方に基準をお くことによって，いくつかの類型にわけることができる と考えられる。本稿はその作業の一部である。

佐伯家住宅は, 富山県民家緊急調査 ${ }^{1)}$ の成果にもとづ き，昭和 45 年に重要文化財に指定され，家作文書も同 侍にその付指定となった。本稿は主として，上記の民家 緊急調查のさいにえた資料によっている。また所蔵者の 佳珄有久氏，福岡町教育長堀部芳端氏には豖作文書につ いて，便宜と御教示をえた。記して感謝の意を表する。

\section{2. 家作文書}

各文费の概要を表一1に示した。これらについて説明 する前に，民家の家作文書 (曾埥文書)についてふれてお こ5。民家の新築・移築・改造あるいは修理にあたって， 普請帳 (勘定帳・見舞帳など)，見積・仕様書，絵困面・ 家相図, 伝票類, 棟札・祈梼札, 建築願書などがしばし ばつくられる。このうち建築嫄書以外は，私的な記録と しての性格を強くもつ。このため記載の方法や内容に一 定の形式はない。しかし記載の内容にはいくつかの傾向 が認められる。このことについて，ここで特にのべない が，佳伯家文書を具体的にみてゆくあいだに随時ふれる であるら。次に佐伯家の各文書の説明に5つろう。

文書概要 文-Aは紙数 30 枚 620 筆からなる。明 和 5 年正月 20 日から 同年 3 月 2 日までの期間にわたっ て, 家の代銀, 人足出面・家 (作) 見舞, 買物の支払な

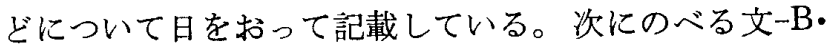
$\mathrm{B}^{\prime}$ ，文-C と一部に重複する記載があるが，内容はもっ とも豊笪で, 值伯家明和年間の家作の基本的なものとす ることができよら。

文-B・B' は文-A の後にとじられている。 $\mathrm{B}$ は表題
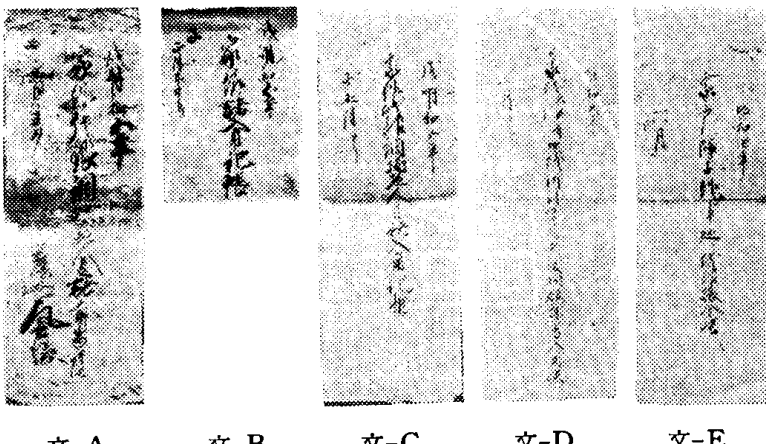

文-B

文-C文-D 文-E

図一2 佐伯家家作文書表紙 
をもつが，B' は表題を欠く。Bは 6 枚 62 筆からなり， 阴和 5 年 2 月 7 日から 9 日までの 3 日間の人足出面を記 している。 $\mathrm{B}^{\prime}$ は 10 枚 288 筆からなり，2月7日から 11 日までの 5 日間の人足仙面，川崎村に泊った人足な どのほか，2月6日から9月，3月14日から16日末で の間の買物等の支払について日をおってて記している。文 - $\mathrm{A}$ ，文- $\mathrm{B}$ ，文-B' の閒には一部に重複する記載がある。

文一C は 5 枚 25 筆加らなる。文一A に続く家代銀の支 払い， 2 月 9.18.20日の調物代, 正月から 2 月にかけて の大工日数の記載などがある。数筆 $\mathrm{B}^{\prime}$ と重複する。

文-D は 4 枚 15 筆からなり，文一C に続く家代銀の支 払い，2月8日加ら 11 日までの川引舟賃，3月2日から 14 日拉よび4月の大工への支払い，3月14 Hのきや方 人への支払の記载がある。数筆 $\mathrm{B}^{\prime}$ と重複する。

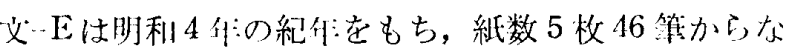
り，建具・造作材料の数最とその代銀を䛉载している。 他上は重複しない。(付資料参照)

記载の重複 以上でタてきたように，一文一は他上

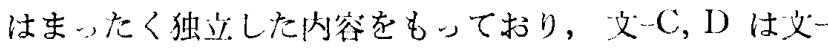
B' とわずかに重複する簓所があるのみで閔題仗すくな い。家代銀の支払については，文-A.C・D にそれぞれ 記載があり，重複しているようにみえるけれども，奏は 支払を順次記しているのであって，これら3 箇所の剖載 をあわせて，まとまった内谷となるのである。重複でも のとも問題が多いのは文-A と B・B にみられるもの で，特に 2 月 7 日から11日までの 5 日間にわたる期間の 人足出面の部分である。いまこの部分に限って，重複の 状況を日ごとに分類すると次のようになる。
イ. 2 月 7 日; 出面は文-A・B・B' の 3 箇所にある。

名前, 人数とも全部一致するから問題はない。

口. 2 月 10 日・11日；10日の出面は文一 $\mathrm{A}$ と $\mathrm{B}^{\prime}$ と にある。名前は一致するが，人数に若干の相違があ る。たとえば「一, 武人伝助」という記載があ りこの人数に違いがある。なお，Aでは大丁の出 面に付落しがある。11日の出闻についても 10 日 とほぼ同様である。

八. 2 月 8 日・ 9 日; いくつかのグループに分かれて 仕事をしており，出面も数箇所にある。たとえば 9 日についてみると， $\mathrm{A} に 2$ 箇所， B 4 箅所， $\mathrm{B}^{\prime}$ に 3 箇所の記載がある。このうち $\mathrm{A}$ と $\mathrm{B}^{\prime}, \mathrm{B}$ と $\mathrm{B}^{\prime}$ のかなりの部分で一致する記載がみられるが，一方 相互の記载の関係が时らかでない部分もあって，川

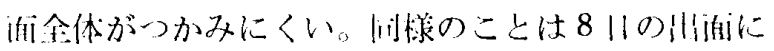
ついていいる。

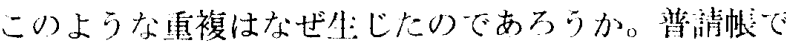
|门じ䛉載内谷の幩泊が 2 册あることは他にも例があり，

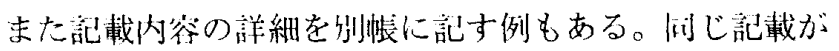
重複して 2 筒所にあることもしばしばみられる。これ は，最初につくのた䐘面や人も整理し，清書したため

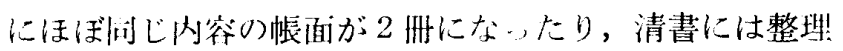
した内無をすせたこ考えられる埸台があり，また时らか に錯誤によって重複しているとみられるものもある。

任伯家の場合, 文-A は文-B・B'を整理したものとみ ることもできる。といらのは $\mathrm{B} \cdot \mathrm{B}^{\prime}$ のほうが $\mathrm{A}$ より詳 しい内谷の部分がかなりある。たとえばAに「一，四拾 武起 馬別帳有」とあり，この別帳は $B^{\prime}$ のことで

表一1 㤢伯家家作文書

\begin{tabular}{|c|c|c|c|c|c|c|c|}
\hline 文畫記号 & 表 & 紙数。 & 筆数 & 記 & 内容（数字筆順） & 期 & 檑 \\
\hline 文-A & $\begin{array}{l}\text { 明和五年正月より } \\
\text { 家作代銀諰物 } \\
\text { 㥎人足啫入用当座帳 }\end{array}$ & 30 & 620 & 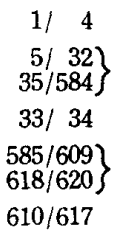 & 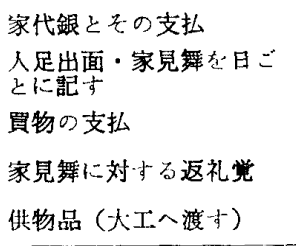 & $\begin{array}{l}5 \text { 年正月 } 20 \text { 日 } / 22 \text { 日 } \\
5 \text { 年正月 } 20 \text { 日 } / 3 \text { 月 } 2 \text { 日 } \\
5 \text { 年 } 2 \text { 月 } 2 \text { 日 } / 3 \text { 日 } \\
? \\
?\end{array}$ & $\begin{array}{l}\text { 人足出面の一部 B. } \\
\text { B }^{\prime} \text { と重複 }\end{array}$ \\
\hline $\begin{array}{l}x-B \\
x \cdot B^{\prime}\end{array}$ & 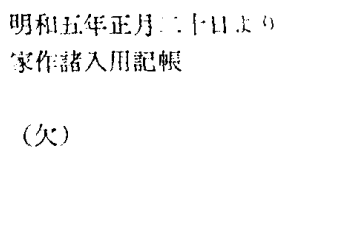 & $\left.\begin{array}{c}6 \\
10\end{array}\right\}$ & 350 & $\begin{array}{r}1 / 62 \\
63 / 88 \\
89 / 255 \\
256 / 266 \\
267 / 311 \\
312 / 350\end{array}$ & 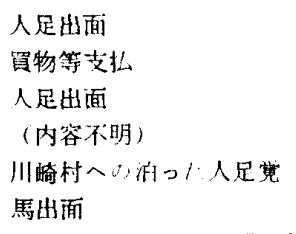 & 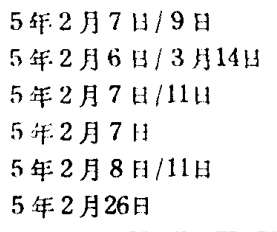 & 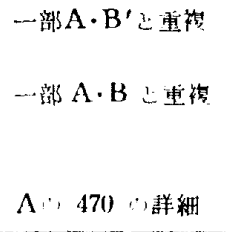 \\
\hline 文-C & 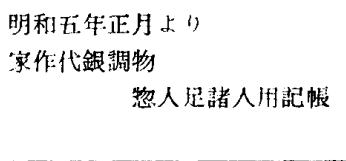 & 5 & 25 & $\begin{array}{rr}1 / & 4 \\
5 / & 17 \\
18 / 24 \\
25 & \end{array}$ & $\begin{array}{l}\text { 家代銀上その支执 } \\
\text { 調物 (釘·箸·竹なと) 代 } \\
\text { 大工日数 (断片的記載) } \\
\text { 家買の人足 }\end{array}$ & $\begin{array}{l}5 \text { 年正月 } 22 \text { 日 } / 2 \text { 月 } 7 \text { 日 } \\
5 \text { 年 } 2 \text { 月 } 9 \text { 日 } / 20 \text { 日 } \\
4 \text { 年 } 12 \text { 月 } / 5 \text { 年 } 2 \text { 月 } 7 \text { U } \\
5 \text { 年正月 } 20 \text { 日 } / 21 \text { 日 }\end{array}$ & \\
\hline$\frac{\dot{x}}{2}-\mathrm{D}$ & $\begin{array}{l}\text { 明和五年二月ょり } \\
\text { 家代銀拉口銭川引運賃調物 } \\
\\
\text { 飯米等入用帳 }\end{array}$ & 4 & 15 & $\begin{array}{rr}1 / & 2 \\
3 / & 8 \\
9 / & 11 \\
12 / & 15 \\
\end{array}$ & $\begin{array}{l}\text { 家代銀とその支払 } \\
\text { 口銭・舟穓の支払 } \\
\text { きやり人への支払 } \\
\text { 職人への支払 }\end{array}$ & $\begin{array}{l}5 \text { 年 } 2 \text { 月 } 7 \text { 日 } / 4 \text { 月 } 7 \text { 日 } \\
? \\
5 \text { 年 } 3 \text { 月 } 14 \text { 日 } \\
?\end{array}$ & \\
\hline 文-E & $\begin{array}{l}\text { 明和四年六月 } \\
\text { 家戸障子作事迴り代銀振分帳 }\end{array}$ & 5 & 46 & $1 / 46$ & $\begin{array}{l}\text { 建具・造作材料の数量々 } \\
\text { その代銀 }\end{array}$ & 4 年 6 月 & \\
\hline
\end{tabular}




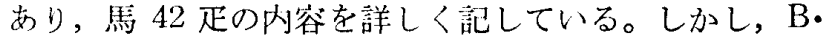
B'にあるのにA にない部載があり，その対の場合も ある。また記載のH付は $\mathrm{A}$ が $\mathrm{B} \cdot \mathrm{B}^{\prime}$ にくらべて早く， Aにオリジナルな䛉載も多いから簡㳯にきめることはで きない。そ机では他にどんなことが考えられるか。記さ れている出闻のH付が B は 2 月 7 日から 9 日， B $^{\prime}$ は 7 日加 11 月に限られていること，この期間は後にのバ るよらにちょらど川崎村から解体した家を運んでいると きであり，人足も川㱦村へ行くもの，残って仕事をして いるもの，その他があって，いくつかのグループにわか

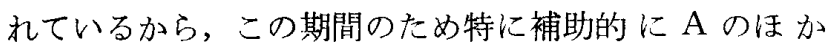
$\mathrm{B} \cdot \mathrm{B}^{\prime}$ の帳湎をつくり，出面の煩雑なのを記録した。そ して，これらをAに整理し記載したが，一部に整理が出 米なかったり，誤った記載があったのではなかろらか。

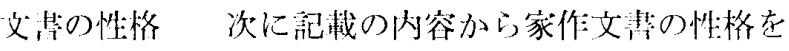
办ると，文一A B' は人起检・勘定邿，C.D.E は勘走帳と考えることが できる。そしてこれらの文書は，村人の乎伝人足の! 泊，家見舞について特に咩しく記録しているこょにひと

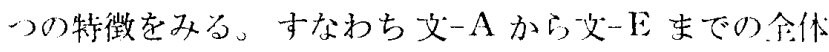
で筆数は 1056 筆で,このらち200 筆はどの重複がある ので,'甚筫は850筆ほど上なりこの80\%以1:0筆数を 人起田而，家見舞の記録でしめているのである。このよ らな特徴はなにも佐伯家の場合に限られたことでなく,

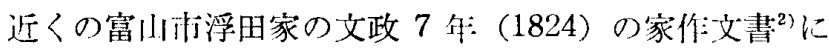
もみられ，またかつて紹介したことのある新鼬県中魚沼 郡中里村の広田家の享和 3 年 (1803) の文書 ${ }^{3}$ にもみら れる。大阪や奈良など近畿地方先進地帯の，このころの 家作文書が収支決算簿として, つまり勘定帳の性格を強 くもっているのが一般的であるのとくらべると，佐伯家 や浮田家, 広田家の場合は人足帳・見舞帳としての性格 が強く, この傾向は北陸地方農村地带の上層民家の家作 文書にみられる特徽ではないかと推定されるのである。 このことについては現在多くの資料をもちあわせていな いが，さらに資料をあつめたいと考えている。

こころで、記のような家作文畫の特徴は，当然家作白

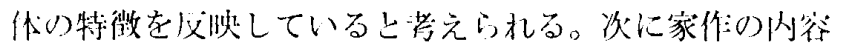
占みてゆくことにしよう。

\section{3. 家 作}

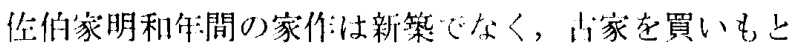
ひ，こ扎移築したりである。その家は川峆村(垷用砥 波郡福野町）の三之助のものであった。川峪村は仯伦家 が所在する蓑囟から小知川の上流 $10 \mathrm{~km}$ ほどのとこ ろにある。(闵-3 参照)

日程 家作は明和 4 年 6 月には始まっている（文一 $\mathrm{E}$, 家作諸入用一巻と題する袋)。象を買亏仲介は水野宮 村の非兵衛がやっており，明和 5 年正月 $20 \cdot 21$ Hの雨日 に，この長兵衛と大工をともなったあわせて 5 人の村人
が家を買いに川崎村に出かけた。続いて 23 日，24日に は家をたてるため屋敷内の整理，27日から翌2月1日 にかけて整地を行ない，この間にこれからの凄中の 生活の利便のために雪隠をつくった。2月7 日からは大 工 2 人と多くの村人の手伝人足が川崎村に行き家の解体 と部材を運びだす用意をした。9日から部材を舟につみ 小矢部川を下った。この琿搬は 13 日まで続く。この間， 大工と手伝人足のうちの数人は川崎村に泊りこんで仕事 をしている。一方家をたてる佐伯家では 2 月 13 日から 本格的な工事にかかる。13 日にはこれまで住んでいた 家を取りこわした。16 日から18 日までの3日間はきや ウ人が入っているので，この間に地突・石場勝など基礎 工事をしたものとおもわれる。村人の手伝も 18 日がも っとも多く，一人びとりの名前を記さず，人足凡 100 人 としている。この川に盛大な儀式的な行事が行なわれた ひであろう。、棟した日の記载はないが，屋根等を2 リ

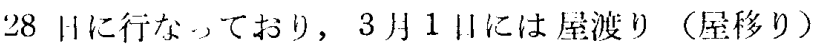
があり，䉼になった家に移り住む儀式を行なっているい で，2 小28川末でには上棟しているはずである。村人

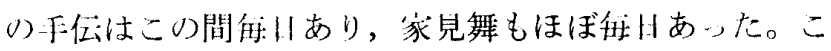

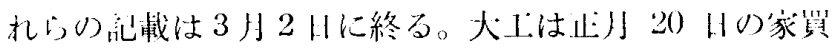

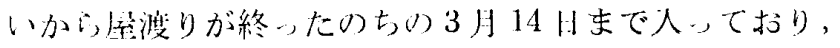
しばらく間を执き４月になって卌び人っている。

表-2 家作費用的内訳

\begin{tabular}{|c|c|c|c|}
\hline 象 & 銀 1 貫 500 多 & 简 & 銭 5 䐝 60 文 \\
\hline 家临口鈛 & 60 多 & 大工手閪 & 3 貫 170 文 \\
\hline 建 具 代 & 311 夕 & きやり人代 & 150 文 \\
\hline 造作材料代 & 676 外 & 諸品買物代 & 4 貫 131 文 \\
\hline 壾 & 銀 2 貫 547 多 & 小 & 銭 12 貫 511 文 \\
\hline
\end{tabular}

家作の費用＼cjkstart文書に記されている家作に関する費用 を合せると, 銀 2 貫 547 外と銭 12 貫 511 文となる（表 一2)。これを金に換算すると䄪 45 両である。ただこの 家作にかかった費用がもれなく記入されているかという と，たとえば調物代や釗代に数量のみ記入してあり，金 額の記入のないものがあり，また記帳が十分に整ってい ない部分があるので，若千の付落しがあると考えられ，

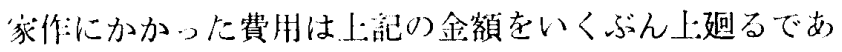
つ5。しかしいずれにしても，家代が銀 1 貫500多で全

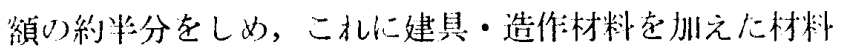
代は全額の9制をこえるもりになっている。

大上等職人 大上レして名解がタえるつは, 福湔町 の甚一郎・甚右衛鬥，矢部村の喜左衛阴の 3 名である。 甚十郎は, 明和 5 年正月 $20 \cdot 21$ 日の出日川崎村人家買 いに行っており, 喜左衛門は正月末から 2 月初にかけて 仕事をしている。この 2 人は 2 月 7 日から 10 日まで川 崎村へ泊りこんで仕事をしており，前にのべたように村 人の手伝もこの時に行っているから，移築する家を解体 し，その指導的な立場にあったとおもわれる。甚右衛門 
については出醇の載がないので具体的なことはわから ない。

大工は家作において主役の役割をはたす職人であり， 出面はもっ上も多く, 仕事の始め, 上棟, 家の完成した ときなど節々の儀式において受けとる祝儀も多いのが普 通である。任伯家の文書には儀式の具体的な様子は記載 されていないが, 供物品として次の品々を大工に渡した ことが記されている。鏡・赫・盃かわらけ・御酒・干 いか・大根・こんぶ・へいぬぬさであり，これらはおそ らく上棟にさいして供えられた品々であろう。

このほか職人とみられるものに，古户出村の三右衛門 が 3 月 2 日から 6 日まで仕事をしており, 戸出村の久次 郎は 6 日から 11 日まで, 中之宮村の甚右衛門は 2 日か ら 14 日上 4 月 1 日から 6 日まで仕事をしている。彼ら はいずれも 1 Hにつき 70 文を受けとっており，代事を している侍期は屋渡りののちであるので，造作にあた。 た大工かあるいは左官など他の職人である川能性もあ る。またきやり人の福润町の平四郎は 2 月16 月から 18 Hまでの 3 H關で, 150 文を受け上てている。このほ か，川崎村か心佳伯家に管の世話をした長兵衛はその山 銭（千数料）として銀 60 多を受けとっている。これは 家代の $4 \%$ \%あたる。

忉料の運搬部材の連搬は注に船・焦によ一た。船は 小神村覚助の长舟 6 艘をたのんで小知部川を「り，津沃 村での川越にはこの朴の入四郎の舟を 2 月 8 日から 10 山までやとった。このほか 2 月 $10 \cdot 11$ 日の 2 日間, 福岡 町平右衛門と又比六方と称する小舟をやとった。舟 賃は長舟 1 艘について 600 文と飯米 1 升宛であり，この 舟には永子 (舟頭) が 2 人宛采り，彼らには飯米 2 升宛 を支払った。津沢での川越舟賃は 3 日で 520 文, いくり 舟賃は 1 日につき 70 文であった。

馬は村人各自がもつものであり，手伝人足上同様，賃 金を支払った記載はない。文書にあらわれる馬は，川崎 村へ部材を運びに行なったもの 42 正, 壁土を運んだも の3 正となって打り，この易会，人足を伴っている。

\section{4. 村人}

家作に执ける林人の役制は一のにわけることができ

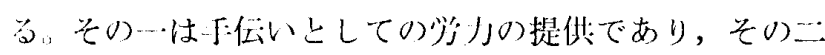
は家見舞上して物品を睓ることであり，その心は家作に

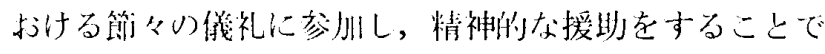

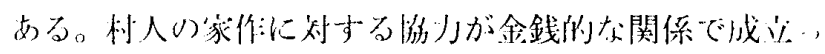
ているものでないこ上は重娶な特徴とみなせよう。佳任 家の象作文書にもこのような村人の名前がひじょうに多 く乨されている。その数は住伯家が所在する萇島の鳳辽 約 40 箇村からあわせて 400 人ほどにのぼっている。

村人の仕事 村人の手伝人足としての仕事を家作文 整加ひろうと, 屋敷内の整理, 整地, 排水の溝掘り, 壁土運び, 川崎村へ行って家の解体とその部材の運搬,

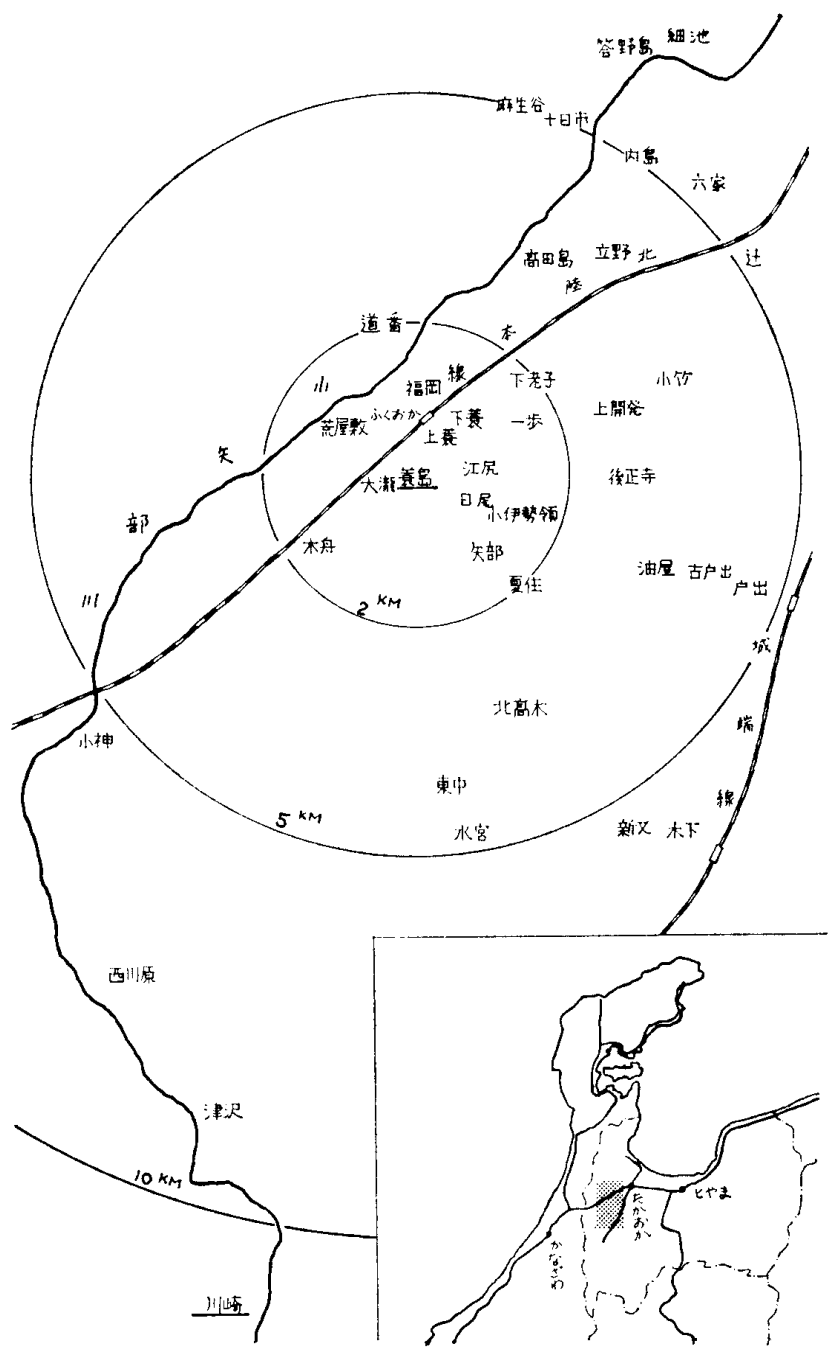

図一3 位伯家の家作に関係した村ヶ

もと住んでいた家の解体，屋根苟，屋移りなどがある。 文書には仕事の内容を記さず，単に「人足」と記してい るものも多く，家作の日程や人足の人数加ら判断する と，仕事の内㝘として地形や家の組立てもあったとおも われる。人足の人数は 2 月 18 日 (地形か) の凡 100 人 を最高として，2月 8 日から 11 日（家の解体と部材運 搬)，16日・17日 (地形か)，27日・28日(屋根葺), 3 月 1 日（屋移り）のときは 20 人を越している。

家見舞家作文書によると，家見舞として贈物を持 のてきた村人は 37 筒村から 100 人で 106 回と数えられ る。2回きたものは 6 人ある。その期間は 2 月 5 月から 至渡りのあった 3 月 2 はまでのほぼ 1 カ月閒で, 見舞の もい上も多かったりは2月18川で40人上なっている。

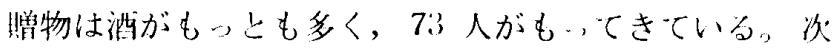

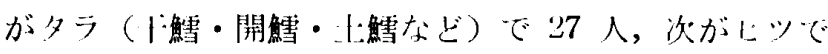

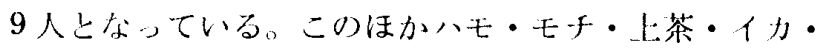
盐引・ウドンほかがあり，ほ上んどが食料品である。1 人が持ってくる品数は 1 種のもの 71 人, 2 種のもの 27 人, 3 種類のもの 3 人となっている。

この家見舞で特徴とおもわれる点は，1）品物は食料 品が多く，建築の材料が少いこと，2）村内（萇島村） や寸ぐ近くの上萇・江尻・矢部・小伊勢領の各村から贈 
物を持って家見舞に来ている人がすくなく，むしろ遠力 の村からの人が多い。これは手伝人足が近くの村から多 くきているのと対照的である。

上記のことや文書の内容を考えあわせると次のような ことが推定される。すなわち，贈物を持ってきたのは， 佐伯家と親類であったり，特に関係の深い家であって， 一般の村人は，村内のものまでふくめて家見舞として上 でのべたような贈物をしていないらしい。ただし，村人 がまったく品物をもってきていないかというと，それは 疑問である。たとえば 2 月 18 日には人足の名前を記さ ず「人足凡 100 人」としているのは，この日には関係す る村人はすべて手伝いに出る慣習になっており，特に名 前を記す必要がなかったといらよらなことが考えられる のであるが，これと同様にたとえば，このHに村人がみ な縄をもってきたが，それはあたりまえのことで，特に 記していない川能性もある。

次任伯家では，手伝いや家兒舞の返礼として，赫 飭・酒・干䱧などを 16 人の村人に配った。配った先は， 手伝人足として多くのH数きた人と，これにまじって乎 伝の日数のすくない人がある。これらは位伯家と特に関 係の梁い家とみる心゙きであるう。

\section{5.むすび}

これまでもしばしばのべたように任伯家の家作文書は 村人に関する記載に多くをあてている。新築でなく移築 亡事であるという事情もあって，大工等職人に関する記 録はすくなく，また支出に関する記載もあまり多くはな い。このことは家作のあり方，さらに経済・社会状沅を

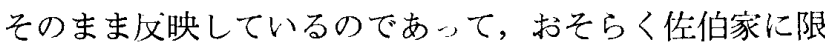
ぎられたことでなく，この地方では一般的なことであ。 たろら。

ところで传伯家の家作は相互扶助的な村人の多くの労 力によって行なわれたのであるが，大阪や奈良など近畿 地方の先進地带, なかでも町場の場合, 江戸時代後期で は村人や町人の相互扶助的な労力は少く,これにかわる 筧力提供者として，職人としての手伝が存在している。

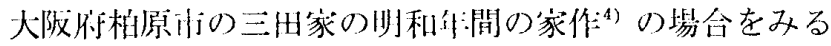

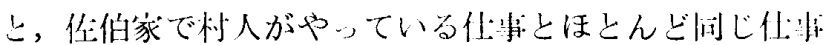
を職人上しての手伝が受掠，ている。

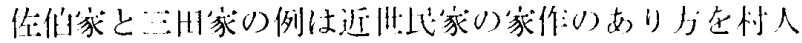

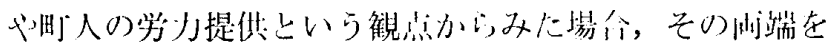

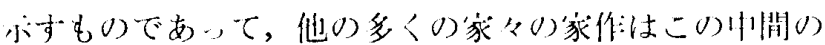

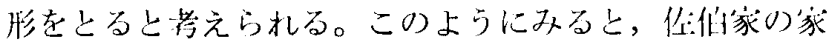
作文書は，前にあげた新潟県の公山家のものとともに，
表 3 人足沺面・家见舞一覧

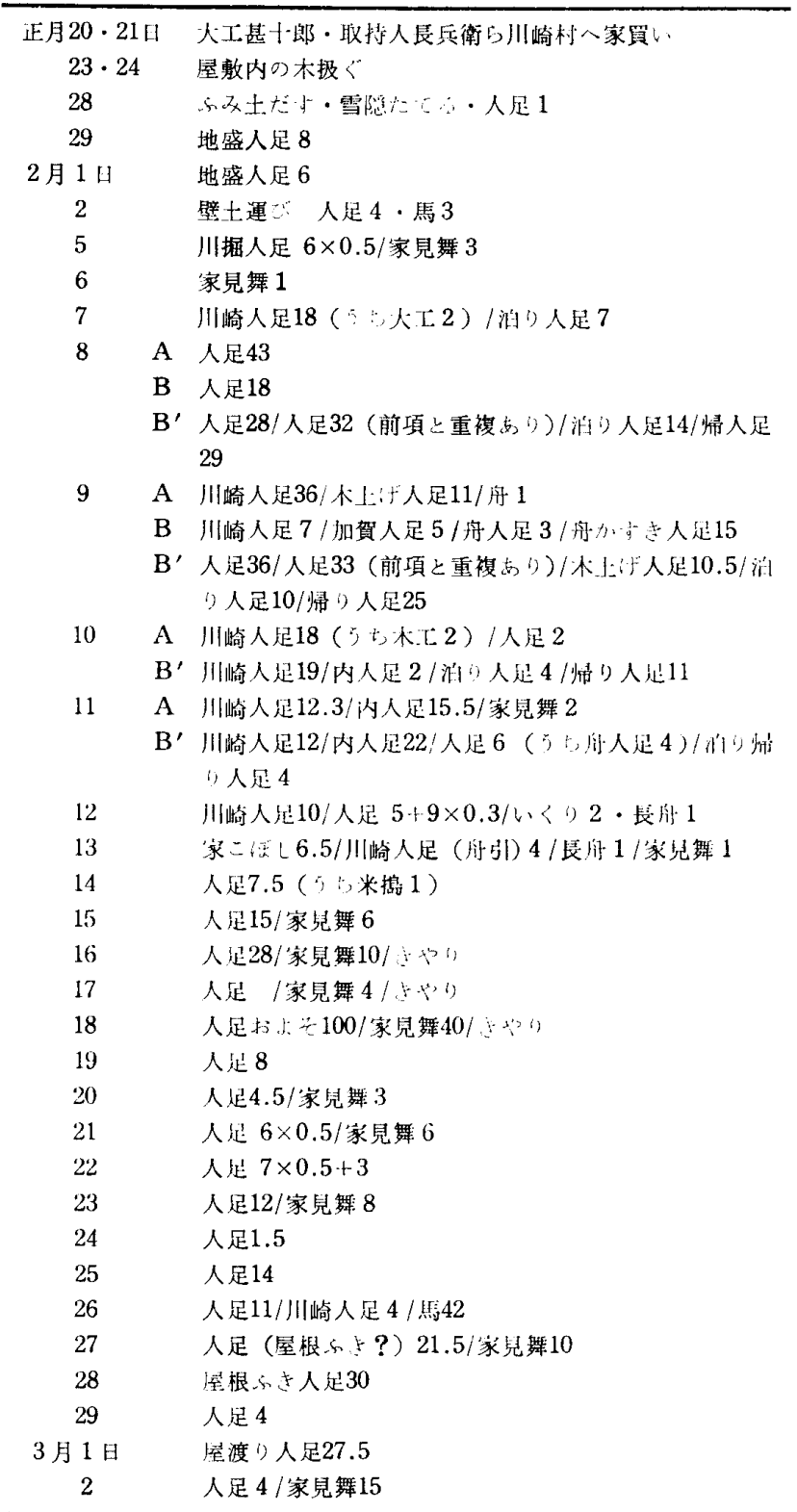

村人が相互扶助的な絶大な労力を提供するといら家作の あり方を示す好個の資料とみなせょう。

(注)

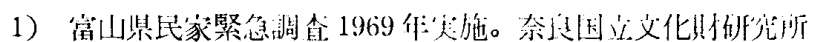
担当。『笛山県尼策』70.2

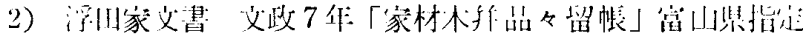
文化財

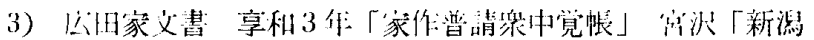

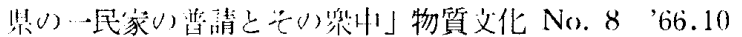

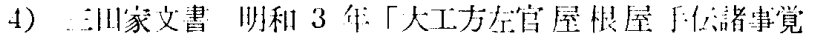

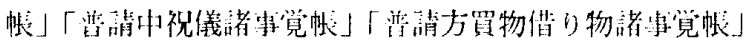

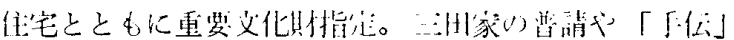

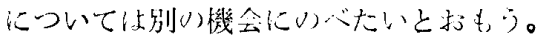




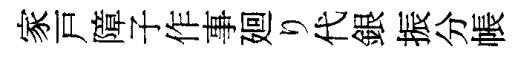

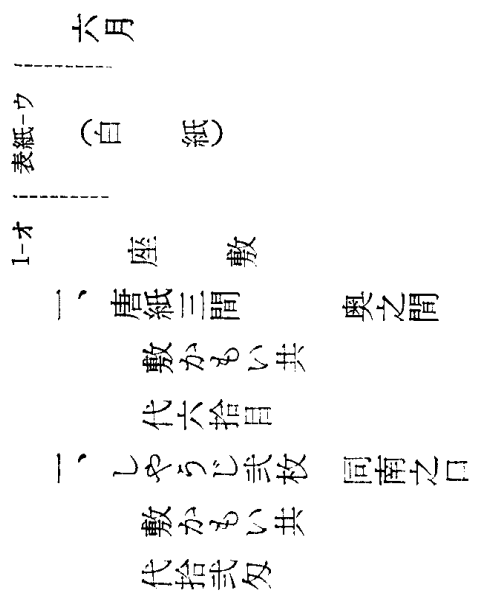

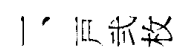

叫我数

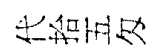

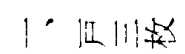

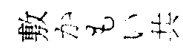
我保他

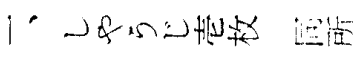

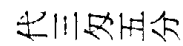

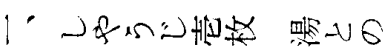

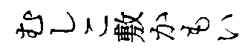

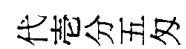

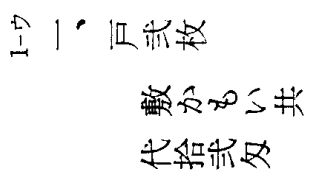

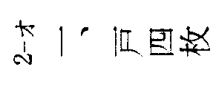

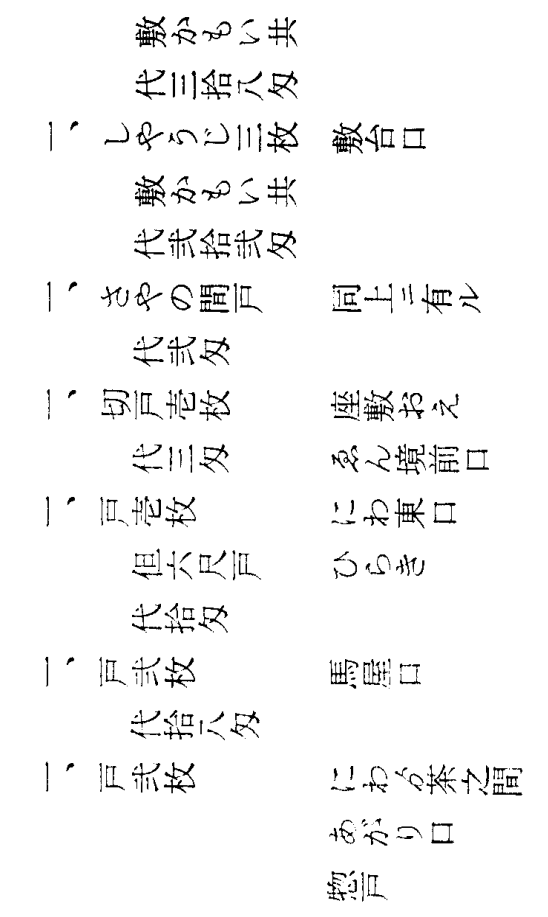

내난

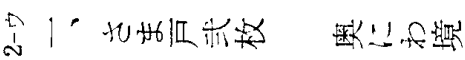 सK屌

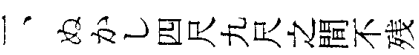

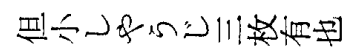

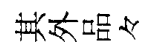
सै+文

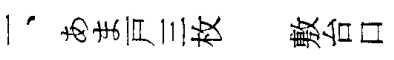
的

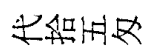

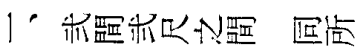

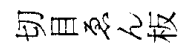
$t \pm N$ 圤际

1 早西的心 स゙川出

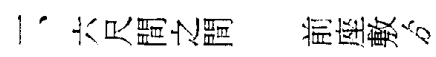

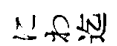

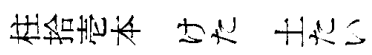

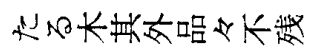
出炏垈四

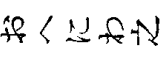
배

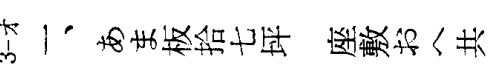

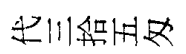

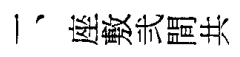

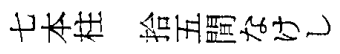

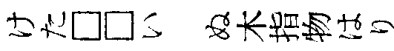

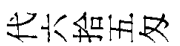

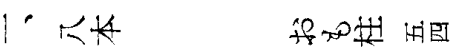

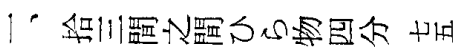

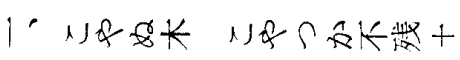

1 推长 thas

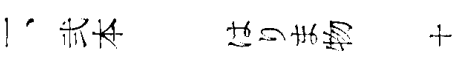

1' 11 世 Etol"

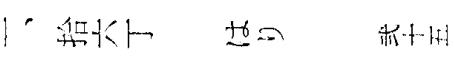

1

$x$

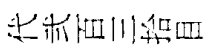

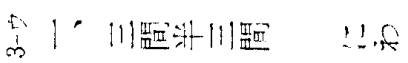

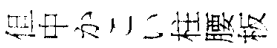

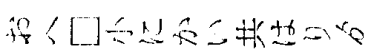

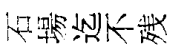

久 甘人垈正

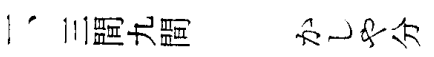
米川㷛用这

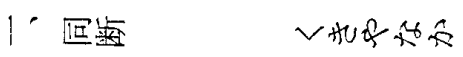

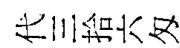

1. 你扎负\&

来林留四

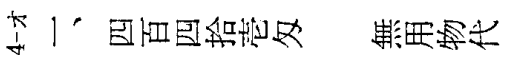

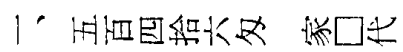

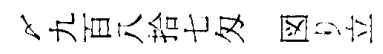

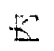

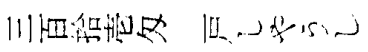
国十11好

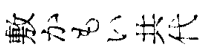

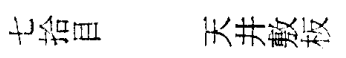

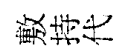

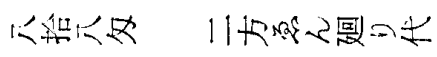

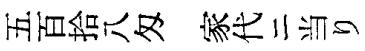




\section{EVALUATION OF SPACIOUSNESS}

(See Trans of A.I.J. No. 192 Page 55)

by MASO INUI, TOSHIMOTO MIYATA, and KEIKO WATANABE

Research of Building Research Institute. Members of A.I.J.

U.D.C. 725.51 .011 .1

\section{A MIXED EXPONETIAL MODEL OF THE HOSPITAL SERVICE AREA}

(See Page 59)

by HIDEHIKO TANIMURA, Assistant Prof. of City Planning University of Manitoba, Member of A.I.J.

U.D.C. $728.6 .03(521.42)$

\section{DOCUMENT ON THE CONSTRUCTION OF THE SAEKIS' HOUSE IN TOYAMA PREFECTURE, 1764}

by SATOSHI MIYAZAWA, Nara National Cultural Propertes Research Institute, Member of A.I.J.

The SAEKI family (in today's Toyama Prefecture) got a new house in 1764 (middle Edo era). They didint build newly, but removed the used one.

They made a document on the construction, which tells us the village people helped the SAEKI family. They helped in two ways, namely with labor and making presents. In the Edo ara it was common to help each other a new house was buit. In the case of the SAEKI family, about 200 peoples from 40 villages went to help and make presents. This number is especially large. This large number was one of the special features which was common to the upper farmers in the Hokuriku district.

U.D.C.72.03:725.21

\section{THE STUDY OF THE SALE AND RECEPTION ROOM OF THE KAITAKUSHI (XIX).}

by AKIHISA ENDO, Member of A.I.J.

This 19 th and the next 20 th reports are the last papers of the series.

In this 19 th report the completion of the building in the 14 th year of Meiji (1881), the report of the KAITAKU. SHI to the government concernning the completion and press news of the time are introduced. And also the official report of the KAITAKUSHI which the completion time was changed intentionally is discussed. The Sale and Reception Room of the KAITAKUSHI was a splendid building that was existent scarcely at that time.

There was a reception room which was composed of a drawing room, a dining roon, a billard room and a bed room in the upstairs.

The actual using circumstance are ascertained through the materials. And the building aim that the reception room was attached to the sale room of the products of Hokkaido are studied in relation to the political stand of the KAITAKUSHI.

As the KAITAKUSHI was abolished in twelve months after the completion under the circumstance which could not display scarcely that function. 